\title{
Palaeoenvironmental data from fluvial deposits associated to ancient fishing weirs in the Miño river, NW Iberia
}

\section{Datos paleoambientales de depósitos fluviales asociados a antiguas presas de pesca en el río Miño, NW Iberia}

\author{
JORGE SANJURJO-SÁNCHEZ ${ }^{* 1}$, CARLOS ARCE CHAMORRO ${ }^{1}$, VÍCTOR \\ BARRIENTOS $^{1}$, ANA GOY-DIZ ${ }^{2}$ \\ ${ }^{1}$ Instituto Universitario de Geología "Isidro Parga Pondal". Universidad de A Coruña, 15071 A \\ Coruña, España. \\ ${ }^{2}$ Facultad de Humanidades, University of Santiago de Compostela. \\ *Autor de contacto: jorge.sanjurjo.sanchez@udc.es
}

\begin{abstract}
Fluvial sediments provide environmental records of the Quaternary. In some cases, fluvial deposits are caused by anthropogenic processes that cause changes in the water regime of some river stretches. This is the case of dams. It has been reported that some dams or partial damming systems existed in the past, at least from some thousands of years ago. Such dams
\end{abstract}


were used for fishing purposes and are referred as fishing weirs. In a recently published work it has been demonstrated that a fluvial thick deposit was caused by a damming system in a river of NW Iberia (River Miño, Pontevedra). Optically stimulated luminescence (OSL) provided the burial age of such fluvial deposit, showing a 1300 -year-old fluvial record. The sedimentation rates of the record did not match with known climate fluctuations in the area. In this work, the sedimentation phases of such record are identified, and the detrital and organic matter content is studied to assess any change occurred in the environmental and fluvial conditions during the deposition period of the record that ranges from $814 \pm 134$ to $1837 \pm 11$ AD.

\section{Resumen}

Los sedimentos fluviales pueden proporcionar registros ambientales del Cuaternario. En algunos casos, los depósitos fluviales pueden ser causados por procesos antropogénicos que provocan cambios en el régimen hídrico de algunos tramos de los ríos. Este es el caso de los actuales embalses. Algunos estudios han mostrado que en el pasado existieron algunas presas o sistemas de represas parciales, desde hace al menos algunos miles de años. Esas presas se utilizaban con fines pesqueros y se denominan fishingweirs o en Galicia pesqueiras. En un trabajo reciente se ha estudiado un depósito fluvial causado por un sistema de embalses en un río del noroeste de la Península Ibérica (rio Miño, Pontevedra). Utilizando luminiscencia estimulada ópticamente (OSL) se pudo datar la edad de deposición de estos sedimentos, obteniéndose un registro fluvial de 1300 años de antigüedad. Las tasas de sedimentación del registro no coincidían con las fluctuaciones climáticas conocidas en la zona. En este trabajo se identifican las fases de sedimentación de ese registro y se estudia el contenido detrítico y la materia orgánica para evaluar los posibles cambios que se hayan producido en las condiciones ambientales y fluviales de ese tramo del río durante el período de deposición del registro, que va de $814 \pm 134$ a $1837 \pm 11$ d.C.

Keywords: Fishing weirs, fluvial sediments, OSL dating, palaeoenvironment

Palabras Clave: Pesqueiras, sedimentos fluviales, datación por OSL, paleoambiente 


\section{INTRODUCTION}

Fluvial sediments preserve records of environmental conditions and events that occurred during the Quaternary. Geochemical analyses of fluvial sediments provide information on the past conditions of the watercourse, seasonality and stagnation events. The structural and textural study and absolute dating of sediment records can provide sedimentation rates, information on erosive events and on process related to the surrounding surface of the fluvial basin (e.g. erosion events, human activities). However, the continuous sedimentary sequences are scarce in most river stretches of most fluvial basins, due to alternative sedimentation or erosive events that can occur due to changing environmental conditions.

Some human-made structures (e.g. dams, or damming systems) can work as base levels in some stretches of fluvial basins, allowing sedimentation in areas where this process would not occur in the absence of such structures. Nowadays, this is common in rivers, but old structures (historic or prehistoric) have been reported. This is the case of fishing weirs. Fishing weirs are amongst the oldest man-made structures found in the archaeological record. Dating back to the Mesolithic and Neolithic (Pedersen, 1995; Out, 2008; McNiven et al., 2012). They consist of series of wooden stakes with a net or basket that trap the fish (Tveskova and Erlandson, 2003); or as a series of stone walls that either trap or guide fish towards a system of channels in which the fish are trapped (Leite, 1999; Langouët and Daire, 2009). They can be dated when made on wood or by organic components present in the deposits formed by the fluvial channel fills or alternatively by optically stimulated luminescence (OSL) as recently has been shown (Viveen et al., 2014).

In NW Iberia a large number of ancient fishing weirs exist (they are popularly called pesqueiras, in Galician), being more frequent in some important rivers or the area, namely Tambre, Ulla and Miño Rivers. They were frequently built in narrow parts of the river channels, such as bedrock gorges or river bends, where the currents were strongest and deposits were not naturally formed. The weirs in the area are series of stone dams, made of non-cemented large granite blocks, that protrude from the river bank at a right angle or slightly sub parallel, depending on the currents (Portela, 1985). More details on the characteristics of these structures are the sub-types of weirs in the area are provided elsewhere. There is very little known about the origins of the weirs in this corner of Iberia, as historical documents are scarce and extensive archaeological studies are still lacking (Reboreda, 2005). Although historical data indicate that Romans used the NW Iberian fish stocks for consumption (Suarez-Piñeiro, 2003) and the trade in these fish stocks intensified from the late 1st century $\mathrm{BC}$ onwards, when the region was brought under control of Rome (Rodríguez-Colmenero, 2011), no direct evidence of Roman weirs exists (Leite, 1999). First direct reference in documents date back to the late Middle Ages, (AndradeCernadas, 2009). Nowadays, some of them still in use for lamprey fishing in the rivers referred above.

\section{STUDY AREA}

We have studied the geochemical characteristics of a $15 \mathrm{~m}$-thick and $50 \mathrm{~m}$ wide fluvial deposit in the lower Miño River (NW 
Iberia) that corresponds to a 1300 -years-old fluvial record. Such deposit has been correlated with the construction of a series of ancient fishing weirs. The deposit consists of homogeneously sorted fine to medium fine sand with mm-thick layers of organic material. This is an extraordinary deposit in the area because it is the only non-gravelly fluvial deposit of the over 400 field sites in the lower Miño River basin that have been described (Viveen et al., 2013). The deposit has been recently studied and dated by OSL (Viveen et al., 2014) being demonstrated that it is the result of partial damming of the Miño River by fishing weirs that caused a deviation of the water course towards a levee (figure 1), that allowed sand deposition during bank full discharge. In fact, up to 18 remnants of weirs have been found in the vicinity of the deposit, some of which are as high as the top of the deposit.

The previous work has suggested the influence of demographic changes on the construction of a series of ancient weirs in the area and the phases of deposition correspond to the usage of the weirs (Viveen et al., 2014). Although the obtained data are consistent with the regional transformation of a predominantly natural to an agricultural landscape in the area, it is still possible to get more information on the environmental conditions and events that occurred during the time of use of the weirs (being characterized by deposition). Thus, the aim of this work is to get light on such environmental conditions towards the study of the characteristics of the sediments, including detrital analyses (grain size, roundness and sphericity) and geochemical analyses of the mineral and organic components of the sediment. Both geochemical elements and stable isotopes of the organic carbon present in the sediment layers have been used to assess the environmental conditions linked to the deposition and the possible effect of anthropogenic process in the surrounding environment in the deposition process. 


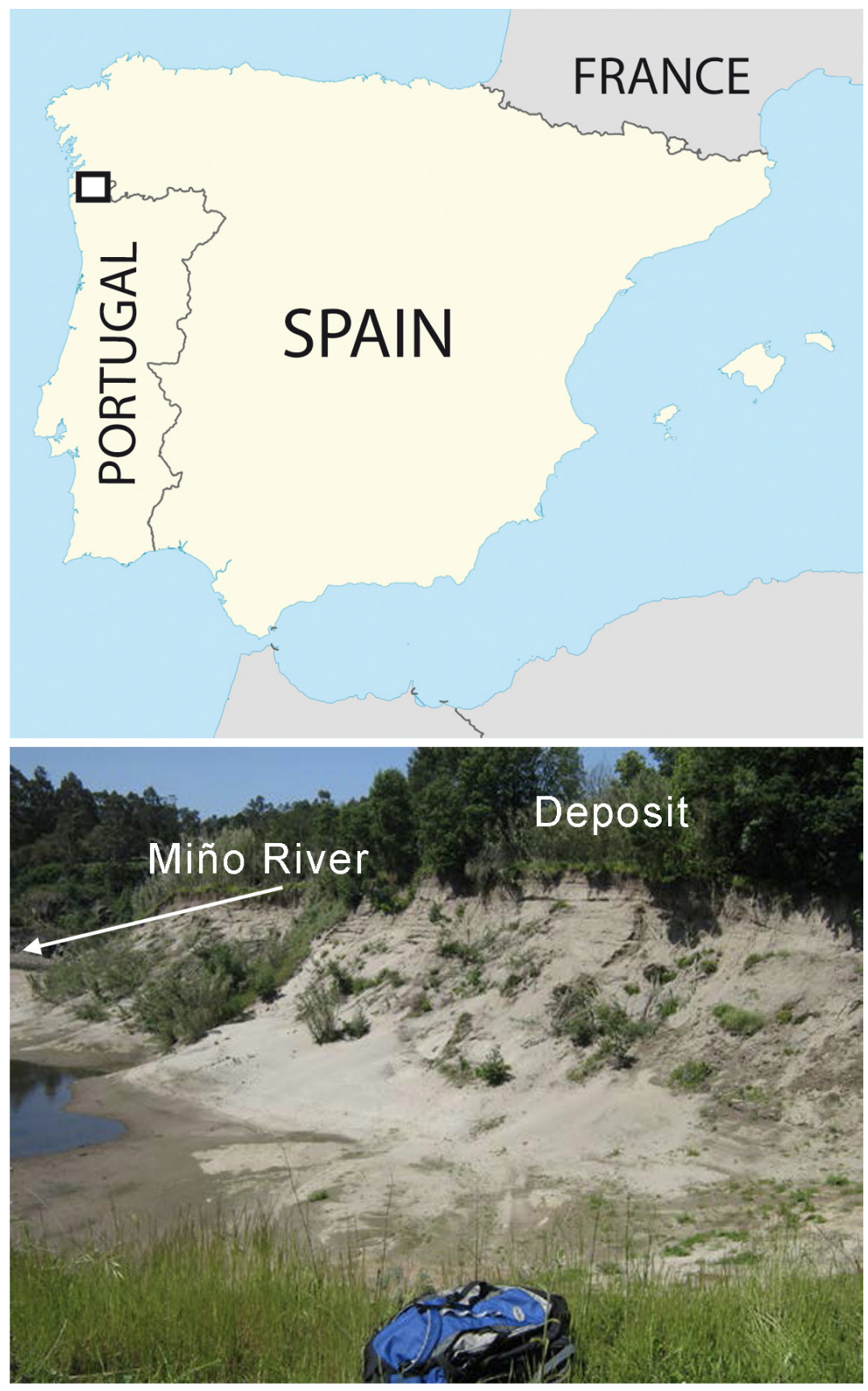

Figure 1. Map of location and picture of the studied deposit. 


\section{METHODS}

\section{Sampling}

A total of 24 samples were retrieved from the deposit. From the uppermost $4 \mathrm{~m}$ samples were directly taken after having cleaned the wall. As the remaining part of the deposit was an inclined slope we dug 6 $m$ depth vertically at the position where the vertical wall started to slope. For the remaining the deposit we cored with an Edelman auger containing an almost fully-closed auger tip, at the bottom of the hole and extracting samples every metre until the very bottom of the fluvial deposit.

\section{OSL measurements}

Cores and plastic bags of sediment were obtained in each sampling point to perform OSL dating in the luminescence lab of the University of ACoruña. Most of the dating work was performed and published elsewhere (Viveen et al., 2014). In this work we have performed three more datings of samples taken from the uppermost $4 \mathrm{~m}$ of the deposit (CDV-19, CDV-21 and CDV-22), being the OSL ages obtained with the procedures applied to the previously dated samples. Details of the used procedures are provided in Viveen et al. (2014). This makes a total of 15 OSL ages in a $15 \mathrm{~m}$-thick deposit.

\section{Geochemical analyses}

One part of the sedimentary material obtained during sampling was used for geochemical studies. Grain size analyses were performed by wet sieving. In addition, the sand-sized fraction of each sample was observed under stereoscopic microscope to as- sess the roundness and sphericity of a subsample of grains. Some other characteristics of the sediment grains were observed under the microscope as the presence of oxides, charcoal and/or remains of herbaceous plants in some samples. To assess the content of major and minor elements in samples we have used X-Ray Fluorescence Spectrometry (XRF). Samples were previously grinded to a fine powder and measured in a Fluorescence Spectrometer S4 Pioneer of wavelength dispersion Bruker-Nonius under helium purge. The obtained data were compared with grain-size and some proxies usually used in fluvial environments were used to assess paleoenvironmental conditions.

Instrumental analyses were carried out on bulk material of the bands to obtain the $\mathrm{C}, \mathrm{H}, \mathrm{O}, \mathrm{N}$ and $\mathrm{S}$ content and the total organic carbon. The analyses were being all of them consistent carried out in an Elemental analyzer ThermoQuest Flash EA 1112. The obtained $\mathrm{C} / \mathrm{N}$ ratios were used to assess the possible origin of organic matter present in the sediments. In addition, $\mathrm{C}$ and $\mathrm{N}$ isotopic analyses were performed in a magnetic sector mass spectrometer with a double inlet system Delta Plus Finnigan MAT to get information on the origin of organic matter within the sediment.

\section{RESULTS AND DISCUSSION}

The obtained OSL ages performed in this work are consistent with the previous ages reported in Viveen et al. (2014). There is an age vs. depth correlation within the measured age uncertainties (see table 1). From the age data we can roughly separate two deposition periods or phases (figure 2): one corresponding to the lowest part of the deposit between $14.7 \mathrm{~m}$ and $4 \mathrm{~m}$ and the other one corre- 
sponding to the samples taken from $4 \mathrm{~m}$ to $0.6 \mathrm{~m}$ depth. Such two periods fall between $814 \pm 134$ and $1031 \pm 70 \mathrm{AD}$, and $1712 \pm 19$ and $1837 \pm 11$ AD, respectively. There is a hiatus with no deposition between $1031 \pm 70$ and $1712 \pm 19 \mathrm{AD}$. It is interesting that the lowermost phase can be divided in several depositional events if we consider the sedimentation rates. Considering such rates, there is a high sedimentation rate from 14.7 to $9.5 \mathrm{~m}$ depth that corresponds to the 8-9th Century (U1). After such period, a different sedimentation rate is observed from 9.5 to $7.8 \mathrm{~m}$ depth (figure 2), that corresponds to the late 9th to 10th centuries (U2). Finally, a higher sedimentation event (figure 2) is observed again for the phase that corresponds to the depths from 7.2 to $4 \mathrm{~m}$ that is dated from in the late 10th to11th centuries (U3). Although no erosive features have been observed in the preserved profile between 4 and $3.6 \mathrm{~m}$ depth, the OSL ages indicated the existence of a hiatus that corresponds to the period between the 11thand 18th Centuries AD. After such sedimentary gap, a new deposition event occurred (figure 2) that corresponds to the uppermost sedimentary unit (U4) starts at $1718 \pm 37 \mathrm{AD}$ and ends at $1837 \pm 11 \mathrm{AD}$.

\begin{tabular}{|l|c|c|c|c|c|r|}
\hline Sample & Depth (m) & DR (mGy/a) & N & Overdispersion (\%) & ED (Gy) & \multicolumn{1}{c|}{ Age (a) } \\
\hline CDV-22 & 0,6 & $4.217 \pm 0.154$ & $36 / 79$ & $19 \pm 4$ & $0.744 \pm 0.038$ & $177 \pm 11$ \\
\hline CDV-21 & 1,2 & $3.457 \pm 0.381$ & $46 / 46$ & $29 \pm 7$ & $0.689 \pm 0.065$ & $199 \pm 29$ \\
\hline CDV-3 & 2 & $2.877 \pm 0.188$ & $51 / 122$ & $25 \pm 5$ & $0.655 \pm 0.040$ & $228 \pm 20$ \\
\hline CDV-13 & 2,7 & $2.880 \pm 0.109$ & $58 / 101$ & $28 \pm 4$ & $0.869 \pm 0.045$ & $302 \pm 19$ \\
\hline CDV-19 & 3,2 & $3.247 \pm 0.386$ & $36 / 55$ & $20 \pm 3$ & $0.803 \pm 0.036$ & $247 \pm 31$ \\
\hline CDV-20 & 3,6 & $3.343 \pm 0.408$ & $49 / 55$ & $10 \pm 1.7$ & $0.989 \pm 0.031$ & $296 \pm 37$ \\
\hline CDV-4 & 4 & $2.892 \pm 0.182$ & $44 / 81$ & $11 \pm 6$ & $3.054 \pm 0.146$ & $1056 \pm 83$ \\
\hline CDV-5 & 5,5 & $2.636 \pm 0.104$ & $48 / 115$ & $24 \pm 5$ & $2.591 \pm 0.154$ & $983 \pm 70$ \\
\hline CDV-6 & 7,2 & $2.539 \pm 0.100$ & $63 / 106$ & $8 \pm 3$ & $2.466 \pm 0.078$ & $971 \pm 49$ \\
\hline CDV-9 & 7,8 & $2.469 \pm 0.117$ & $50 / 83$ & $17 \pm 3$ & $2.794 \pm 0.123$ & $1132 \pm 73$ \\
\hline CDV-10 & 8,8 & $2.744 \pm 0.120$ & $55 / 71$ & $12 \pm 2$ & $3.255 \pm 0.112$ & $1186 \pm 66$ \\
\hline CDV-11 & 10 & $2.761 \pm 0.134$ & $55 / 118$ & $8 \pm 2$ & $3.533 \pm 0.114$ & $1279 \pm 75$ \\
\hline CDV-12 & 10,8 & $2.744 \pm 0.120$ & $50 / 114$ & $12 \pm 3$ & $3.390 \pm 0.145$ & $1235 \pm 76$ \\
\hline CDV-15 & 13 & $2.832 \pm 0.076$ & $42 / 87$ & $15 \pm 3$ & $3.542 \pm 0.217$ & $1251 \pm 84$ \\
\hline CDV-17 & 14,7 & $2.693 \pm 0.285$ & $51 / 97$ & $23 \pm 3$ & $3.230 \pm 0.112$ & $1200 \pm 134$ \\
\hline
\end{tabular}

Table 1. OSL ages obtained of the deposit. DR: Dose Rate, ED: Equivalen Dose).

Considering the total thickness of the deposit and the whole timespan of deposition we obtain a high bulk deposition rate around $1.5 \mathrm{~cm} \cdot \mathrm{a}-1$. The grain size shows a log-normal unimodal symmetric distribu- tion dominated by fine to medium-size sand (ranging from more than $30 \%$ to $90 \%$ ) with minor silt (15-40\%) and scarce clays (0.5-6$6 \%$ ) that indicates a high speed flux in the water channel. This is similar to other grain 
sizes described fluvial deposits (Ramaswamy et al.,2008; Kao et al., 2006; Dinakaran et al., 2011; Blanton et al., 1995) but in an area in which this kind of deposits is not observed. This non-expected grain size in a stacked water body can be explained because the weirs in the area were not closed dams, but damming systems that did not completely block the river flow (Viveen et al., 2014). Both roundness and sphericity values of the studied samples showed homogeneous and mean values are 0.3 and 0.7 respectively, typical of fluvial deposits with moderate transport (Krumbein, 1948; Kumbrein and Sloss, 1963), despite the possible stagnation effect caused by the weirs.

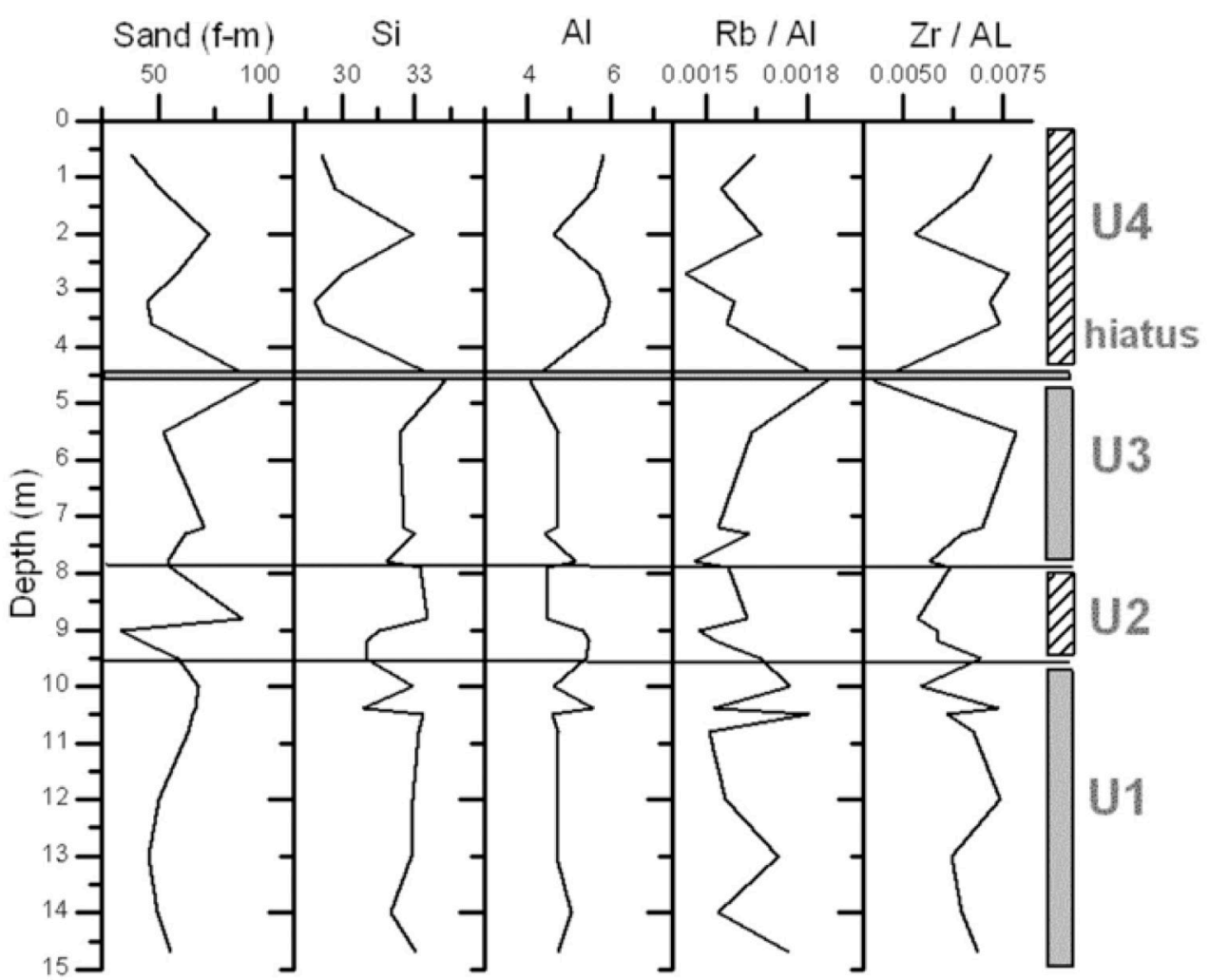

Figure 2. Plot with fluctuations of grain size and detrital proxies with depth. Sand percent is indicated and compared with both $\mathrm{Si}$ and $\mathrm{Al}$ contents and $\mathrm{Rb} / \mathrm{AL}$ and $\mathrm{Zr} / \mathrm{Al}$ ratios.

There is very low organic matter content in the studied samples (figure 3). The organic matter is linked to the silty-clay fraction as observed in similar sediments (Keil et al.,1997; Mayer et al., 1994), except in the case of two samples at located 10.5 and 7.3 $\mathrm{m}$. The organic carbon content ranges from 0.8 to $1.2 \%$, while the $\mathrm{N}$ content ranges from 0.02 to $0.07 \%$, and increases with the sediment depth, being variable from the bottom 
to the top of the lowermost $10 \mathrm{~m}$ of deposit. This is clearly observed by the $\mathrm{C} / \mathrm{N}$ ratios observed. The measured $\mathrm{C}$ and $\mathrm{N}$ stable isotope relations of the organic matter, provided $\delta 13 \mathrm{C}$ values ranging from-26.0\% to $-24.3 \%$, and $\delta 15 \mathrm{~N}$ values that range from 1.7 to $4.5 \%$ (figure 3 ). Such values fit the range observed in fluvial sediments from terrestrial primary $(\mathrm{C} 3)$ and freshwater production (phytoplankton) (O'Leary, 1988; Meyers and Lellier-Vergès, 1999; Peterson and Fry, 1987; Finley and Kendall, 2005).

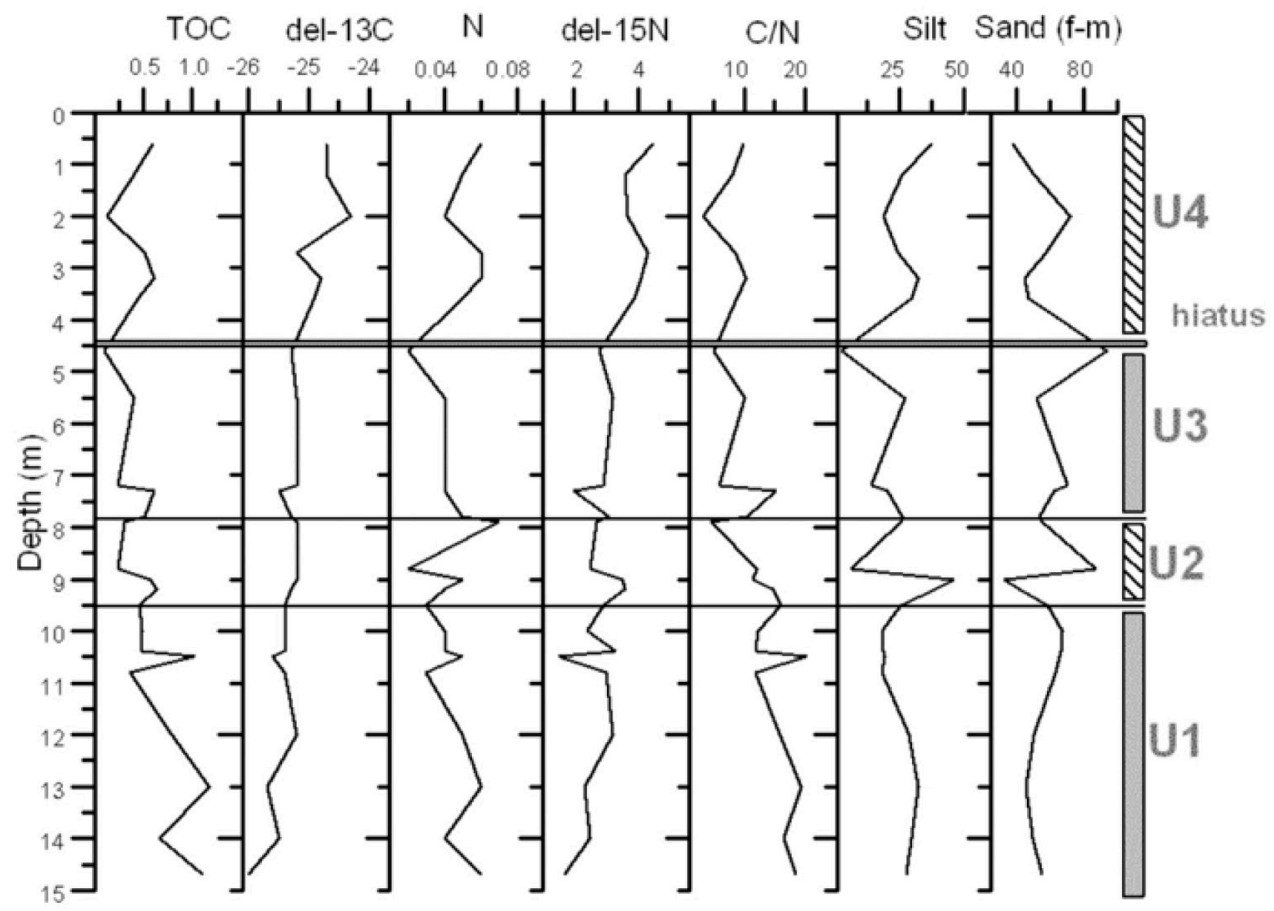

Figure 3. Plot with fluctuations of grain size, TOC, $\mathrm{N}$ and $\mathrm{C} / \mathrm{N}$ ratio and $\delta 13 \mathrm{C}$ and $\delta 15 \mathrm{~N}$.

The results of XRF analyses allowed to study the changes in the $\mathrm{Si}$ and $\mathrm{Al}$ content. These contents are correlated with the amount of sand-grained grains in each sample. The $\mathrm{Rb} / \mathrm{Al}$ and $\mathrm{Zr} / \mathrm{Sl}$ ratios (figure 2) are also used and compared. In the next paragraphs, we detail the sediment characteristics observed for each sedimentation period with correlation with environmental and anthropogenic events recorded in other studies in the area.

\section{Period of 8 and 9th Century (U1)}

Such period corresponds to the U1 (figures 2-3). The thickness of the fist sedimentary period (U1) is around $\sim 5.2 \mathrm{~m}$, deposited in approximately one century, with a very high sedimentation rate $(\sim 5.2 \mathrm{~cm}$ a-1). Slight fluctuations are observed in the grain size of samples of such period and the estimated TOC and $\mathrm{N}$ tend to decrease in the uppermost layers. The $\mathrm{C} / \mathrm{N}$ ratio provides 
values $>15$, correlated with allochthonous organic matter inlets up to $13 \mathrm{~m}$ depth, mixture of allochthonous and autochthonous matter between 12 and $10 \mathrm{~m}(\mathrm{C} / \mathrm{N} \sim 10-14)$ with a peak of allochthonous organic matter at $10.5 \mathrm{~m}$ depth. The $\mathrm{C} / \mathrm{N}$ fluctuations fit changes in both the $\delta 13 \mathrm{C}$ and the $\delta 15 \mathrm{~N}$, but changes in these values does not show any change in the primary production process. Thus, in the period, there is a general increase in the heavy isotope in both elements, but organic matter comes from inlets of terrestrial vegetation. This is due to the increase in the inlet of detrital and organic matter but both indicate high erosion rates in the basin and high deposition rates, probably correlated with the increase of precipitation and floods or an increase in the deforestation and wildfire caused by the man, as it has been observed in the area in such period (Viveen et al., 2014). There is an inverse correlation of $\mathrm{Si}(\sim 70 \%)$ and $\mathrm{Al}(\sim 20 \%)$ in such sedimentation period despite in the $10.5 \mathrm{~m}$ depth layer, but detrital fluvial input proxies show a scarce correlation and they show an inverse correlation compared to the grain size. Due to the high mass accumulation rate of sediment (MARs) in such period (being $7.3510-6 \mathrm{mg} \cdot \mathrm{cm}-2 \cdot \mathrm{a}-1)$ it is difficult to infer other conclusions. This effect could be correlated to the unusual sedimentation rate in the period that fits the Medieval Climate Anomaly (MCA) in the NW of Iberia with an observed increase of fluvial input in the Atlantic continental shelf of Iberia (Lebreiro et al., 2006). It has been reported that there is an increase in the sand-size grain frequency in the Miño and Duero Rivers in such period (Mohamed et al., 2010) and evidences of several flood events in such period (Thorndycraft and Benito, 2006). This trend is opposite to the trend observed in the rest of Iberia, especially in the central and Mediterranean area, in which the MCA is characterized by dry conditions (Moreno et al.,2012).

\section{Period from late 9th to 10th Century (U2)}

This period comprises around another 100 years of deposition with the accumulation of $\sim 1.7 \mathrm{~m}$ of sediment, being the sedimentation rate $\sim 1.7 \mathrm{~cm} \cdot \mathrm{a}-1$. Thus, a lower MARs value is observed in this period (3.88 $10-6 \mathrm{mg} \cdot \mathrm{cm}-2 \cdot \mathrm{a}-1)$. There is a slight increase in the silty-grain size (figure 2), $\mathrm{N}$ and TOC content from the bottom to the top of the sediment section with a slight fluctuation between $9 \mathrm{~m}$ depth (increase) and $8.8 \mathrm{~m}$ depth (decrease), increasing again up to the values observed in the previous period (U1) with the exception of the TOC values (figure 3 ). This is due to the low inlet of allochthonous organic matter. As a consequence, the $\mathrm{C} / \mathrm{N}$ ratio reaches mean values above 10 at the beginning of the period and $<10$ at the end. This suggests an increase in the primary production in the water body (autochthonous organic matter) probably due to a decrease in the water flux and more stacked conditions. In this period the $\mathrm{C} / \mathrm{N}$ fluctuations fit fluctuations in both the $\delta 13 \mathrm{C}$ and the $\delta 15 \mathrm{~N}$, keeping the trend to increase in the heavy isotope in both elements.

Detrital proxies show an event dated in $1186 \pm 66 \mathrm{yr}$ that indicate an increase in dryness marked by the higher concentration of $\mathrm{Zr}(\mathrm{Zr} / \mathrm{Al})$ and $\mathrm{Ti}$ (Ti/Al), respect to $\mathrm{Si}$ (Si/Al) and a later decrease with increase of water flux as observed in the slight increase of $\mathrm{Si}, \mathrm{Rb}$ and $\mathrm{Mg}$ ( $\mathrm{Si} / \mathrm{Al}, \mathrm{Rb} / \mathrm{Al}$ and $\mathrm{Mg} / \mathrm{Al}$, respectively). This fit the increase of the fine to medium grain size at $8.8 \mathrm{~m}$ depth (Makenzie, 2005). 


\section{Period from late 10th to 11th Century (U3)}

This period corresponds to $3.2 \mathrm{~m}$ sediment thickness in around 100 years, providing a sedimentation rate of $\sim 3.2 \mathrm{~cm} \cdot \mathrm{a}-1$ and a MARs of $4.5810-6 \mathrm{mg} \cdot \mathrm{cm}-2 \cdot \mathrm{a}-1$. The trends in this period are similar to those observed during the first period (U1) but with lower TOC values (figure 3). The grain size is more fluctuating with an increase in the sand-size fraction with a maximum $(\sim 70 \%)$ at $7.3 \mathrm{~m}$ depth that fits a maximum TOC content $(0.6 \%)$ in the period. The trend of both the $\delta 13 \mathrm{C}$ and the $\delta 15 \mathrm{~N}$ are the same than in previous periods. Allochthonous inlets of organic matter are observed, being the organic matter in the other moments of such period due to a mixture of allochthonous and autochthonous matter. With time the allochthonous contribution decreases in favour to autochthonous contributions of organic matter. This can be due to the accumulation of sediments with a decrease in the depth of the water (and decrease in the water body volume) with more stacked conditions. Thus, in the three first periods, during stagnation events caused by seasonal or climatic dry periods, there is a probable increase of primary production within the water body with a decrease in the gaseous $\mathrm{CO} 2$ in the water (and a subsequent decrease in the light isotope of $\mathrm{C}$ ) that is more frequent due to the infill of the area (Meyers, 1998; Meyers y Lellier-Vergès, 1999). At the top of the sediment section $(4 \mathrm{~m})$ there is a new sand-size frequency maximum (more than $90 \%$ ) at which TOC and $\mathrm{N}$ values are minimum $(0,1$ and $0.02 \%$, respectively). This can be due to a decrease in the organic matter inlet or a post-depositional degradation.

Although climatic fluctuations can be responsible of the fluctuations in the sediment characteristics we cannot rule out that the decrease in TOC observed in U1, U2 and $\mathrm{U} 3$ is due (partially or totally) to anthropogenic causes. It has been observed that there are important changes in vegetation in the area. Namely, a decrease in autochthonous tree species (Quercus, Alnus) and an increase in both shrubby (Ulex, Erica, Calluna, etc.) and herbaceous plants (Poaceae and Cyperaceae) has been reported in correlation with the increase of farming areas and wildfires in the Medieval period (Pallarés and Portela, 2007), as it has been observed in pollen records and anthracological studies (Mighall et al., 2006; Desprat et al, 2003; Martinez-Cortizas et al., 2005;Carrión et al, 2010; Kaal et al., 2011).

In the next $\sim 500$ years there is a sedimentary hiatus. This has been correlated with the destruction of the weirs that caused the deposition, due to strong flooding events in such period (as discussed in detail in Viveen et al., 2014). In this period, there is an increase in the $\mathrm{Si}$ and $\mathrm{Rb}$ content despite an observed $\mathrm{Zr}$ content $(\mathrm{Zr} / \mathrm{Al})$ that fits the lower amounts of fine-medium sand content (figure 2). This can be linked to an event of dryness increase.

\section{Period from $1718 \pm 37$ to $1837 \pm 11$ AD (U4)}

The uppermost sedimentary section has an approximate thickness of $4 \mathrm{~m}$, accumulated in a period of $\sim 150$ years. That makes a sedimentation rate of $2.6 \mathrm{~cm} \cdot \mathrm{a}-1$. This value is similar the one observed in U3 but with higher MARs values $(6.1510-6 \mathrm{mg} \cdot \mathrm{cm}-$ $2 \cdot a-1)$ that could be correlated with a higher accumulation of organic matter. In this section, the amount of silt sized grains increases while fine-medium sand size decreases with fluctuations at $2 \mathrm{~m}$ depth. The changes 
and fluctuation in both the TOC and N fits the silt sized grains pattern (figures 2-3). This trend is observed with some detrital proxies. Such proxies show a good correlation with changes in the grain size, suggesting higher grain size in moments of higher water flux, being clear the inverse correlation between sand grains and the values of $\mathrm{Ti} / \mathrm{Al}$ and $\mathrm{Zr} / \mathrm{Al}$ (figure 2). This period fits the Little Ie Age (LIA), characterized by a general decrease in the mean surface temperature in the Northern Hemisphere and oscillations of periods of dryness and floods (Benito 1996; Álvarez Vázquez et al., 1986) in the NW of Iberia. Such climatic fluctuations would fit the marked fluctuations observed in the sediment. Between 1856-1909 $\mathrm{AD}$ flooding occurred in the Miño River (Abrantes et al., 2011), possibly eliminating the weirs and thus, hardly any sedimentation occurred after such event although it must not be ruled out that the height of the deposit fits the height of the top of the remains of the weirs in the considered river stretch.

\section{CONCLUSIONS}

The study of fluvial deposit caused by a weir in NW Iberia has provided a 1300year old fluvial record (with a hiatus of $\sim 500$ years). The deposition events have been correlated with demographic causes but also the effect of climatic fluctuations, and namely, those due to the Medieval Climate Anomaly (MCA) and the Little Ice Age (LIA). Changes in the grain size mostly match the use of fluvial proxies, being apparently sensitive to periods of drier or more humid conditions in the area. The TOC and total N content of the sediments and $\mathrm{C}$ and $\mathrm{N}$ stable isotopes fit such observations but also other questions, such as a reduction in the depth of the water body due to the infill of the damming area, also can be the cause of such changes in the organic matter. Moreover, it cannot be ruled out that the studied period is characterized by important anthropogenic changes induced in the area due to an expansion of the farming area, at least at the beginning of the record.

The most interesting question in this work is that any similar human-made structure developed in water channels (weirs, dams, water mills) could cause similar deposits in river stretches or periods in which there is not sedimentation, allowing the study of fluvial and environmental records in areas of periods in which sediments are absent.

\section{REFERENCES}

Abrantes, F., Rodrigues, T., Montanari, B., Santos, C., Witt, L., Lopes, C., Voelker, A.H.L., 2011. Climate of the last millennium at the southern pole of the North Atlantic Oscillation: an inner-shelf sediment record of flooding and upwelling. Climate Research 48, 261-280. https:// doi.org/10.3354/cr01010

Álvarez Vázquez, J.A., 1986. Drought and rainy periods in the province of Zamora in the 17th, 18th and 19th centuries. In: López Vera, F. (Ed.) Quaternary Climate in the Western Mediterranean. Universidad Autónoma de Madrid, pp. 221-233

Andrade-Cernadas, J.M. 1995. O tombo de Celanova. Santiago de Compostela, Consello da Cultura Galega.

Benito, G. Machado, M. J., Pérez-González, A., 1996. Climate change and flood sensivity in Spain. In: Branson, J.; Brown, A. G.; Gregory, K. J. (Eds.) Global Continental Changes: The Context of Palae- 
ohydrology. Geological Society Special Publication 115. pp. 95-98

Blanton, M. L., Gardiner, W.W., Dirkes, R. L., 1995. Environmental Monitoring of Columbia River Sediments: Grain-Size Distribution and Contaminant Association. U.S. Department of Energy. Battelle Memorial Institute. Pacific Northwest Laboratory Richland, Washington 99352.

Carrión, Y., Kaal, J., López-Sáez, J.A., López-Merino, L., Martínez Cortizas, A., 2010. Holocene vegetation changes in NW Iberia revealed by anthracological and palynological records from a colluvial soil. The Holocene 20, 53-66. http:// dx.doi.org/10.1177/0959683609348849

Desprat, S., Sánchez-Goñi, M.F., Loutre M.F., 2003. Revealing climatic variability of the last three millennia in northwestern Iberia using pollen influx data. Earth and Planetary Science Letters 213, 63-78. https://doi.org/10.1016/S0012821X(03)00292-9

Dinakaran, J., Krishnayya, N.S.R., 2011. Variations in total organic carbon and grain size distribution in ephemeral river sediments in western India. International Journal of Sediment Research 26 239-246. https://doi.org/10.1016/S10016279(11)60090-5

Finlay, J.C., Kendall, C., 2007. Stable isotope traceng of temporal and spatial variability in organic matter sources to freshwater ecosystems. In: Michener and Lajtha (Eds) Stable isotopes in ecology and environmental science (2nd Ed.) Blackwell Publishing Ltd., pp. 238-333. https://doi. org/10.1002/9780470691854.ch10

Kaal, J., Carrión-Marco, Y., Asouti, E., Martín-Seijo, M., Martínez- Cortizas, A., Costa-Casáis, M., Criado-Boado, F.,
2011. Long-term deforestation in NW Spain: linking the Holocene fire history to vegetation change and human activities. Quaternary Science Reviews 30, 161-175. https://doi.org/10.1016/j.quascirev.2010.10.006

Kao, S.-J; Shiah, F.-K.;Wang, C.-H.; Liu, K.-K., 2006. Efficient trapping of organic carbon in sediments on the continental margin with high fluvial sediment input off southwestern Taiwan. Continental Shelf Research. 26, 2520-2537. https://doi.org/10.1016/j.csr.2006.07.030

Keil R.G., Mayer L.M., Quay P.D., Richey J.E., Hedges J.I., 1997. Loss of organic matter from riverine particles in deltas. Geochimica et Cosmochimica Acta 61, 1507-1511. https://doi.org/10.1016/ S0016-7037(97)00044-6

Krumbein, W.C., 1941. Measurement and geological significance of shape and roundness of sedimentary particles. Journal of Sedimentary Petrology 11, 64-72.

https://doi.org/10.1306/D42690F3-2B2611D7-8648000102C1865D

Krumbein,W.C., Sloss, L.L., 1963. Stratigraphy and sedimentation (2nd Ed.)W.H. Freeman and co. San Francisco, 660 pp. Langouët, L., Daire, M.-Y., 2009. Ancient Maritime Fish-Traps of Brittany (France): A Reappraisal of the Relationship between Human and Coastal Environment During the Holocene. Journal of Maritime Archaeology 4 (2), 131148. https://doi.org/10.1007/s11457-0099053-2

Lebreiro, S.M.; Francés, G.; Abrantes, F.F.G.; Diz, P.; Bartels-Jónsdottir, H.B.; Stroynowski, Z.N.; Gil, J.M.; Pena, L.D.; Rodrigues, T.; Jones, P.D.; Nombela, M.A.; Alejo, I.; Briffa, K.R.; Harris, I.; 
Grimalt, J.O., 2006. Climate changes and coastal hydrographic response along the Atlantic Iberian margin (Tagus Prodelta and Muros Ría) during the last two millennia. The Holocene 16, 7. SAGE Publications, pp. 1003-1015. https://doi. org/10.1177/0959683606h1990rp

Leite, A., 1999. As pesqueiras do Rio Minho. Economia, sociedade e patrimonio. COREMA - Associação de Defensa do Patrimonio, Caminha, Portugal, 349 pp. Makenzie, F.T. (ed.), 2005. Sediments, Diagenesis and Sedimentary Rocks: Treatise on geochemistry. Vol. 7. Elsevier LTD.

Martinez-Cortizas, A., Mighall, T., Pontevedra-Pombal, X., Novoa-Muñoz, J.C., Peiteado-Varela, E., Piñeiro-Rebolo, R., 2005. Linking changes in atmospheric dust deposition, vegetation change and human activities in northwest Spain during the last 5300 years. The Holocene. 15(5): 698-706 https:// doi.org/10.1191/0959683605h1834rp

McNiven, I.J., Crouch, J., Richards, T., Dolby, N., Jacobsen, G., Gunditj Mirring Traditional Owners Aboriginal Corporation, 2012. Dating Aboriginal stone-walled fishtraps at Lake Condah, southeast Australia. Journal of Archaeological Science 39 (2), 268-286. https:// doi.org/10.1016/j.jas.2011.09.007

Mayer, L.M., 1994. Surface area control of organic carbon accumulation in continental shelf sediments. Geochimica et Cosmochimica Acta 58, 12711284. https://doi.org/10.1016/00167037(94)90381-6

Meyers, P.A., 1994. Preservation of source identification of sedimentary organic matter during and after deposition. Chemical Geology 144, 289-302. https:// doi.org/10.1016/0009-2541(94)90059-0

Meyers, P.A., 2003. Applications of organic geochemistry to paleolimnological reconstructions: a summary of examples from the Laurentian Great Lakes. Organic Geochemistry 34, 261-289. https:// doi.org/10.1016/S0146-6380(02)00168-7

Meyers, P. A., Lallier-Vergès, E., 1999. Lacustrine sedimentary organic matter records of Late Quaternary paleoclimates. Journal of Paleolimnology 21, 345-372. https://doi.org/10.1023/A:1008073732192

Mighall, T.M., Martínez Cortizas, A., Biester, H., Turner, S.E., 2006. Proxy climate and vegetation changes during the last five millennia in NW Iberia:Pollen and non-pollen palynomorph data from two ombrotrophic peat bogs in the North Western Iberian Peninsula. Review of Paleobotany and Palynology 141, 203-233. https://doi.org/10.1016/J. REVPALBO.2006.03.013

Moreno, A., Pérez,A., Frigola, J., NietoMoreno, V., Rodrigo-Gámiz, M., Martrat, B., González-Sampériz, P., Morellón, M., Martín-Puertas, C., Corella, J.P., Belmonte, A., Sancho, C., Cacho, I., Herrera, G., Canals, M., Grimalt, J.O., Jiménez-Espejo, F., Martínez-Ruiz, F.,Vegas-Vilarrúbia， T., Valero-Garcés, B.L., 2012. The Medieval Climate Anomaly in the Iberian Peninsula reconstructed from marine and lake records. Quaternary Science Reviews 43, 16-32. https://doi.org/10.1016/j.quascirev.2012.04.007

Mohamed, K.J., Rey, D., Rubio, B., Vilas, F., Frederichs, T., 2010. Interplay between detrital and diagenetic processes since the last glacial maximum on the northwest Iberian continental shelf. Quaternary Research, 73. Elsevier Inc., 
pp. 507-520. https://doi.org/10.1016/j. yqres.2010.02.003

Pallarés, M.C., Portela, E., 2007. Estructuras agrarias y cambio social en la Galicia de la Edad Media. Una propuesta de lectura histórica del paisaje pp: 37-54. Actas de I Encuentro Compostelano de Arqueología Medieval: Del Documento Escrito a la Evidencia Material. Ed. Lóstrego. Santiago de Compostela.

Pedersen, L., 1995. 7000 years of fishing: stationary fishing structures in the Mesolithic and afterwards. In: Fischer, A. (Ed.), Man and Sea in the Mesolithic: Coastal settlement above and below present sea level. Oxbow Books, Oxford, pp. 75-86.

Peterson, B.J., Fry, B., 1987. Stable isotopes in ecosystem studies. Annual Reviews of Ecological Systems 18, 293 320. https://doi.org/10.1146/annurev. es. 18.110187 .001453

Portela, C., 1985. As pesqueiras do rio Miño. Monografias do Patrimonio Monumental Galego. Direccion Xeral do Patrimonio Artistico e Monumental, Santiago de Compostela, Spain, 46 pp.

O'Leary, M.H., 1988. Carbon isotopes in photosynthesis. Bioscience 38, 328-336.

https://doi.org/:10.2307/1310735

Out, W.A., 2008. Selective use of Cornussanguinea L. (red dogwood) for neolithic fish traps in the Netherlands. Environmental Archaeology 13(1), 1-10. https:// doi.org/: 10.1179/174963108X279184

Ramaswamy, V., Gaye, B., Shirodkar, P.V., Rao, P.S., Chivas, A., Wheeler, D., Thwin, S., 2008. Distribution and sources of organic carbon, nitrogen and their isotopic signatures in sediments from the Ayeyarwady (Irrawaddy) continental shelf, northern Andaman Sea. Ma- rine Chemistry 111, 137-150. https://doi. org/10.1016/j.marchem.2008.04.006

Reboreda, A., 2005. As pesqueiras do Miño: patrimonio en perigo. Cerna, revista galega de ecoloxía e medio ambiente, 43, 30-31.

Rodríguez-Colmenero, A., 2011. Lucus Augusti: a cidade romano-xermánica da Fisterra Ibérica, xenése e evolución histórica (14 a. C.- 711d. C.). Lugo, Concello de Lugo.

Suárez-Piñeiro, A.M., 2003. La explotación del mar en la Galicia romana: el ejemplo de las instalaciones de salazón. Cuadernos de estudios gallegos, 116, 9-25. https://doi.org/ 10.3989/ceg.2003.v50. i1 16.120

Thorndycraft, V.R., Benito, G., 2006. Holocene fluvial chronology of Spain: evidence from a newly complied radiocarbon database. Quaternary Sciences Reviews, 25, 223-234. Elsevier Ltd. https:// doi.org/10.1016/j.quascirev.2005.07.003

Tveskova, M.A., Erlandson, J.M., 2003. The Haynes Inlet weirs: Estuarine fishing and archaeological site visibility on the southern Cascadia coast. Journal of Archaeological Science 30 (8), 1023 1035. https://doi.org/10.1016/S03054403(02)00291-1

Viveen, W., Schoorl, J.M., Veldkamp, A., van Balen, R.T., Vidal-Romani, J.R., 2013. Fluvial terraces of the NW Iberian lower Miño River. The Journal of Maps 9 (4), 513-522. https://doi.org/10.1080/17 445647.2013.821096

Viveen, W., Sanjurjo-Sánchez, J., Goy-Diz, A., Veldkampd, A., Schoorl, J.M., 2014. Paleofloods and ancient fishing weirs in NW Iberian rivers. Quaternary Research 82, 56-65. https://doi.org/10.1016/j. yqres.2014.04.011 
